\title{
Physical Properties of Seeds of Eleven Spruce Species
}

\author{
Zdzisław Kaliniewicz $^{1, * \mathbb{D}}$, Zbigniew Żuk ${ }^{1}$ and Elżbieta Kusińska ${ }^{2}$ \\ 1 Department of Heavy Duty Machines and Research Methodology, University of Warmia and Mazury in \\ Olsztyn, ul. Oczapowskiego 11, 10-719 Olsztyn, Poland; zbigniew.zuk@uwm.edu.pl \\ 2 Department of Engineering and Food Machinery, University of Life Sciences in Lublin, ul. \\ Doświadczalna 44, 20-280 Lublin, Poland; elzbieta.kusinska@up.lublin.pl \\ * Correspondence: zdzislaw.kaliniewicz@uwm.edu.pl; Tel.: +48-089-523-3934
}

Received: 22 August 2018; Accepted: 5 October 2018; Published: 9 October 2018

\begin{abstract}
Information about the variations and correlations between the physical properties of seeds is essential for designing and modeling seed processing operations. The aim of this study was to determine the variations in the basic physical properties of seeds of selected spruce species and to identify the correlations between these attributes for the needs of the seed sorting processes. Terminal velocity, thickness, width, length, mass, and the angle of external friction were determined in the seeds of 11 spruce species. The measured parameters were used to calculate three aspect ratios (geometric mean diameter, sphericity index, and specific mass) of each seed. The average values of the basic physical properties of the analyzed seeds were determined in the following range: terminal velocity- 5.25 to $8.34 \mathrm{~m} \mathrm{~s}^{-1}$, thickness- 1.10 to $2.32 \mathrm{~mm}$, width-1.43 to $3.19 \mathrm{~mm}$, length -2.76 to $5.52 \mathrm{~mm}$, the angle of external friction-23.1 to $30.0^{\circ}$, and mass-2.29 to $18.57 \mathrm{mg}$. The seeds of Jezo spruce and Meyer's spruce were most similar to the seeds of other spruce species, whereas oriental spruce seeds differed most considerably from the remaining seeds. Our findings indicate that spruce seeds should be sorted primarily with the use of mesh sieves with longitudinal openings to obtain fractions with similar seed mass and to promote even germination.
\end{abstract}

Keywords: seeds; physical properties; range of variation; correlations; sorting

\section{Introduction}

Spruce (Picea) trees belong to the pine family (Pinaceae) and are characterized by a regular conical crown relative to other conifers. Depending on species, spruces reach the height of $20 \mathrm{~m}$ to nearly $100 \mathrm{~m}$ at full maturity [1,2]. Approximately 40 spruce species have been identified to date, and all of them reside in the northern hemisphere [1,3-7]. Spruces are the predominant tree species in extensive boreal forests [8-12]. They have higher soil requirements than pines, and they thrive on brown sandy loam and loamy sand soils $[7,13]$. Spruces have high soil and air moisture requirements, and they are sensitive to frost. The discussed species are susceptible to strong winds on account of their shallow root system and thick crown. The risk of tree toppling is exacerbated when the tree stand is rapidly uncovered or considerably thinned. Spruces are shade-tolerant, and their canopies create a unique microclimate that is characterized by significant shading, lower temperature, and higher humidity relative to the surroundings $[2,11,14,15]$.

Spruces have more or less quadrangular, sharply pointed needles that are spirally arranged on all sides of the twig. Needle length ranges from 5 to $50 \mathrm{~mm}$ in various spruce species $[1,5,7]$. Needles are shed every 4 to 12 years, and they are replaced with new growth [1]. Young spruce shoots are abundant in vitamin $\mathrm{C}$, and they are a popular folk remedy for coughs, colds, respiratory ailments, and pain. Spruce oil has antibacterial and antifungal properties [16-20]. In survival situations, spruce needles can be directly consumed or boiled into tea. Spruce needles have high water content, and they 
provide an alternative means of hydration. Spruce needles, young twigs, and essential oils are used to brew spruce beer. Spruce seeds and young plants are readily consumed by various forest animals, which often cause substantial damage to spruce stands [16-20].

In spring, spruces produce cones that ripen 4 to 8 months later in autumn. Cones initially grow upright on the branches, but they begin to hang down in successive stages of maturation. Depending on the species, cones have the length of 2 to $20 \mathrm{~cm}$, and they are yellow-green, red to dark purple in color [1]. Each scale covers two brown-black seeds, which are usually released when the cone falls to the ground. Seeds have an average length of 2 to $7 \mathrm{~mm}$, and the size and quality of spruce seeds is generally determined by genetic factors, as well as climate and weather conditions [21-24].

Information about the variations and correlations between the physical properties of seeds is essential for designing and modeling seed cleaning, sorting, storing, sowing, and processing operations [25,26]. Seed viability, germinative energy, and germination capacity are the main determinants of seed quality [27]. According to many authors, germination efficiency is largely correlated with seed mass, but plumper seeds do not always germinate faster than small seeds [27-34]. In tree nurseries, seeds are sorted into different size fractions to promote even germination. This approach creates equal opportunities for seedling growth and decreases competition between seedlings [35]. Plants grown from sorted seeds are more uniform and are characterized by similar morphological parameters. However, in large production plants, seeds are difficult to sort based on their mass only. Seeds can be sorted with the use of vibratory and vibratory-pneumatic separators [25], but only if the particles differ in dimensions but have similar mass, or if they differ in mass but have similar dimensions. The above devices are not highly effective in separating spruce seeds that differ both in mass and dimensions. For this reason, other parameters that are highly correlated with seed mass have to be identified to facilitate sorting operations.

The aim of this study was to determine the variations in the basic physical properties of seeds of selected spruce species and to identify the correlations between these attributes for the needs of the seed sorting processes.

\section{Materials and Methods}

\subsection{Sample Preparation}

The basic physical properties of seeds of 11 spruce species were analyzed (Figure 1): blue spruce (Picea pungens Engelm.), Jezo spruce (Picea jezoensis Siebold \& Zucc.), Lijiang spruce (Picea likiangensis Franch.), Meyer's spruce (Picea meyeri Rehd. \& E.H.Wilson), Morinda spruce (Picea smithiana Wall.), Norway spruce (Picea abies L.), oriental spruce (Picea orientalis L.), red spruce (Picea rubens Sarg.), Schrenk's spruce (Picea schrenkiana Fish. \& C.A.Mey.), Sitka spruce (Picea sitchensis Bong), and white spruce (Picea glauca Moench). Seeds were obtained in 2017 from Dendrona in Pęcice, a supplier of tree, shrub, perennial plant, and herbaceous plant seeds.

Seed samples for analysis were obtained by halving [27]. Every batch of seeds was halved, and one half was randomly selected for successive halving. The above procedure was repeated to produce samples of around 100 seeds each. The analyzed samples contained 93 to 116 seeds.

\subsection{Physical Properties}

Terminal velocity $(v)$ was determined in the Petkus K-293 pneumatic classifier to the nearest $0.11 \mathrm{~m} \mathrm{~s}^{-1}$, and basic seed dimensions were measured under the MWM 2325 laboratory microscope (length $L$ and width $W$ ) and with a thickness $(T)$ gauge to the nearest $0.01 \mathrm{~mm}$. The angle of external friction $\alpha$ was determined on a steel friction plate (surface roughness- $R a=0.48 \mu \mathrm{m}$ ) positioned on a horizontal plane to the nearest $1^{\circ}$, and seed mass $m$-on the WAA $100 / \mathrm{C} / 2$ laboratory scale to the nearest $0.1 \mathrm{mg}$. The measurements were conducted based on the method described by Kaliniewicz et al. [36,37] and Kaliniewicz and Poznański [38]. The angle of external friction was expressed as the mean value of two measurements where seeds were arranged in different positions: 
with the longitudinal axis parallel and perpendicular to the direction of movement on the steel friction plate.

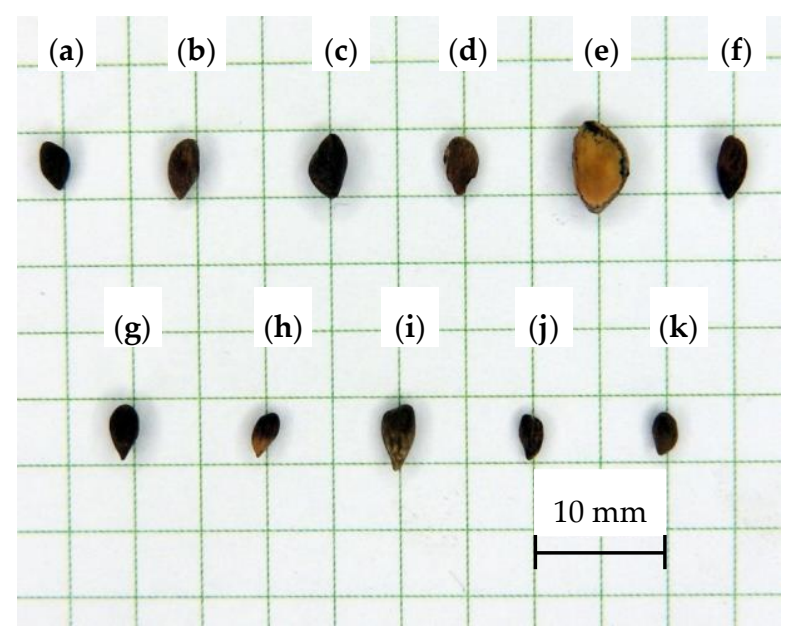

Figure 1. Seeds of: (a) blue spruce, (b) Jezo spruce, (c) Lijiang spruce, (d) Meyer's spruce, (e) Morinda spruce, (f) Norway spruce, (g) oriental spruce, (h) red spruce, (i) Schrenk's spruce, (j) Sitka spruce, (k) white spruce.

The aspect ratios $(T / W, T / L$, and $W / L)$, geometric mean diameter $D$, and sphericity index $\Phi$ were determined for each seed [39]:

$$
\begin{gathered}
D=(T \times W \times L)^{\frac{1}{3}} \\
\Phi=\frac{D}{L} \times 100
\end{gathered}
$$

Specific mass was determined for each seed [40]:

$$
m_{D}=\frac{m}{D}
$$

Seeds were divided into three roughly equal groups based on their thickness: fine seeds (group I—thinnest seeds), medium-sized seeds (group II—seeds with average thickness), and large seeds (group III—thickest seeds). Seed thickness was measured to the nearest $0.05 \mathrm{~mm}$.

\subsection{Statistical Analysis}

The measured physical parameters of seeds were processed in Statistica PL v. 12.5 at a significance level of $\alpha=0.05$. The differences between the measured properties were determined by one-way analysis of variance (ANOVA). The normality of each group was verified by the Shapiro-Wilk test, and the equality of variances was assessed with Levene's test. If the null hypothesis, which postulated that the average values of a given parameter in the analyzed seed species are equal, was rejected, the significance of differences was determined and homogenous groups were identified with the use of Duncan's test. A correlation analysis was performed to determine the strength and direction of the correlations between the analyzed seeds parameters. The degree of correlation was evaluated with the use of Pearson's correlation coefficient. The functions describing the correlations between the physical parameters of seeds were determined by regression analysis [41]. These equations were selected by testing the functions available in the Statistica package. The function that most closely resembled the cloud of measurement points and was characterized by a high coefficient of determination was selected. A large number of statistically significant regression equations were obtained; therefore, only the equations with a minimum coefficient of determination of 0.8 were presented in the paper. 


\section{Results}

\subsection{Experimental Material}

The accuracy with which the mean values of the analyzed physical parameters are determined can be inferred from their standard error of the estimate based on the size of the sample, standard deviation of the examined parameter, and Student $t$-values at a given significance level. The analyzed samples consisted of 93 to 116 seeds; therefore, the standard error of the estimate of the mean values of the evaluated physical properties of spruce seeds did not exceed:

- for terminal velocity $-0.25 \mathrm{~m} \mathrm{~s}^{-1}$,

- for basic dimensions (thickness, width and length) $-0.1 \mathrm{~mm}$,

- for the angle of external friction- $1.2^{\circ}$,

- $\quad$ for seed mass- $0.7 \mathrm{mg}$.

The results of the Shapiro-Wilk test and Levene's test revealed that the assumptions for ANOVA were met because the analyzed parameters and indicators had near normal distribution, and the variations in parameter values were uniform in all populations.

The physical properties of the analyzed seeds are presented in Table 1 . The average terminal velocity ranged from $5.3 \mathrm{~m} \mathrm{~s}^{-1}$ (Schrenk's spruce) to $8.3 \mathrm{~m} \mathrm{~s}^{-1}$ (Morinda spruce). The following spruce species formed homogeneous groups in terms of terminal velocity: (1) Jezo spruce, red spruce, and white spruce; (2) Lijiang spruce, Meyer's spruce, and Schrenk's spruce.

Table 1. Statistical distribution of the physical properties (mean value \pm standard deviation) of seeds in selected spruce species and significant differences between species.

\begin{tabular}{|c|c|c|c|c|c|c|}
\hline \multirow[b]{2}{*}{ Spruce Species } & \multicolumn{6}{|c|}{ Property } \\
\hline & $\begin{array}{c}\text { Terminal } \\
\text { Velocity } v \\
\left(\mathrm{~m} \mathrm{~s}^{-1}\right)\end{array}$ & $\begin{array}{l}\text { Thickness } T \\
\text { (mm) }\end{array}$ & $\begin{array}{l}\text { Width } W \\
\text { (mm) }\end{array}$ & $\begin{array}{l}\text { Length } L \\
\quad(\mathrm{~mm})\end{array}$ & $\begin{array}{c}\text { Angle of } \\
\text { External } \\
\text { Friction } \alpha\left(^{\circ}\right)\end{array}$ & $\begin{array}{l}\text { Mass } m \\
\quad(\mathrm{mg})\end{array}$ \\
\hline Blue spruce & $6.1 \pm 0.5^{c}$ & $1.44 \pm 0.13^{c}$ & $1.77 \pm 0.18^{c}$ & $3.70 \pm 0.34^{\mathrm{d}}$ & $27 \pm 4^{\mathrm{c}}$ & $4.2 \pm 0.9^{c}$ \\
\hline Jezo spruce & $5.8 \pm 1.1^{b}$ & $1.49 \pm 0.18^{\mathrm{d}}$ & $1.98 \pm 0.27^{\mathrm{d}}$ & $3.91 \pm 0.41^{\mathrm{e}}$ & $29 \pm 6^{\mathrm{d}, \mathrm{e}}$ & $4.8 \pm 2.0^{\mathrm{d}}$ \\
\hline Lijiang spruce & $6.4 \pm 0.9^{\mathrm{d}}$ & $1.63 \pm 0.20^{\mathrm{f}}$ & $2.13 \pm 0.28^{\mathrm{e}}$ & $4.46 \pm 0.42 \mathrm{~g}$ & $29 \pm 4^{\mathrm{d}, \mathrm{e}}$ & $7.0 \pm 2.0^{f, g}$ \\
\hline Meyer's spruce & $6.5 \pm 0.7^{\mathrm{d}}$ & $1.53 \pm 0.18^{\mathrm{e}}$ & $2.00 \pm 0.26^{\mathrm{d}}$ & $3.92 \pm 0.42^{\mathrm{e}}$ & $29 \pm 5^{\mathrm{d}, \mathrm{e}}$ & $6.1 \pm 1.7^{\mathrm{e}}$ \\
\hline Morinda spruce & $8.3 \pm 0.6^{g}$ & $2.32 \pm 0.18^{g}$ & $3.19 \pm 0.29 \mathrm{~g}$ & $5.52 \pm 0.44^{h}$ & $23 \pm 2^{a}$ & $18.6 \pm 3.1^{\mathrm{h}}$ \\
\hline Norway spruce & $7.6 \pm 0.9^{f}$ & $1.54 \pm 0.20^{\mathrm{e}}$ & $2.19 \pm 0.26^{f}$ & $4.23 \pm 0.48^{\mathrm{f}}$ & $29 \pm 5^{\mathrm{e}}$ & $6.9 \pm 2.3^{f, g}$ \\
\hline Oriental spruce & $6.9 \pm 0.7^{\mathrm{e}}$ & $1.63 \pm 0.16^{\mathrm{f}}$ & $2.08 \pm 0.26^{\mathrm{e}}$ & $3.98 \pm 0.38^{\mathrm{e}}$ & $26 \pm 4^{b}$ & $6.5 \pm 1.8^{\mathrm{e}, \mathrm{f}}$ \\
\hline Red spruce & $5.7 \pm 0.7^{b}$ & $1.21 \pm 0.12^{b}$ & $1.61 \pm 0.20^{b}$ & $3.15 \pm 0.29^{c}$ & $29 \pm 5^{\text {d,e }}$ & $3.0 \pm 0.8^{b}$ \\
\hline Schrenk's spruce & $6.6 \pm 0.9^{d}$ & $1.63 \pm 0.16^{\mathrm{f}}$ & $2.24 \pm 0.27^{\mathrm{f}}$ & $4.54 \pm 0.42^{g}$ & $28 \pm 5^{\mathrm{c}, \mathrm{d}}$ & $7.4 \pm 1.9 \mathrm{~g}$ \\
\hline Sitka spruce & $5.3 \pm 0.4^{\mathrm{a}}$ & $1.10 \pm 0.11^{\mathrm{a}}$ & $1.47 \pm 0.23^{\mathrm{a}}$ & $2.97 \pm 0.24^{b}$ & $30 \pm 5^{\mathrm{e}}$ & $2.3 \pm 0.5^{a}$ \\
\hline White spruce & $5.79 \pm 0.6^{b}$ & $1.21 \pm 0.14^{b}$ & $1.43 \pm 0.17^{\mathrm{a}}$ & $2.76 \pm 0.22^{a}$ & $29 \pm 5^{\mathrm{d}, \mathrm{e}}$ & $2.4 \pm 0.6^{a}$ \\
\hline
\end{tabular}

The average seed thickness ranged from $1.10 \mathrm{~mm}$ (Sitka spruce) to $2.32 \mathrm{~mm}$ (Morinda spruce). Seed thickness was similar in the seeds of Meyer's spruce and Norway spruce, as well as in Lijiang spruce, oriental spruce, and Schrenk's spruce. The following spruce species formed homogeneous pairs in terms of seed width: Sitka spruce and white spruce, Jezo spruce and Meyer's spruce, Lijiang spruce and oriental spruce, Norway spruce and Schrenk's spruce. The average seed width ranged from $1.43 \mathrm{~mm}$ (white spruce) to $3.19 \mathrm{~mm}$ (Morinda spruce), and the average seed length ranged from $2.76 \mathrm{~mm}$ (white spruce) to 5.52 (Morinda spruce). The following spruce species formed homogeneous groups in terms of seed length: Jezo spruce, Meyer's spruce, and oriental spruce, as well as Lijiang spruce and Schrenk's spruce.

Only minor variations were noted in the average angle of external friction, which ranged from $23^{\circ}$ (Morinda spruce) to $30^{\circ}$ (Sitka spruce). The smallest angle of external friction was noted in Morinda spruce and oriental spruce, which differed from the remaining spruce species in this respect. 
The average seed mass ranged from $2.3 \mathrm{mg}$ (Sitka spruce) to $18.6 \mathrm{mg}$ (Morinda spruce). The following spruce species formed homogeneous groups in terms of seed mass: Sitka spruce and white spruce; Meyer's spruce and oriental spruce; Lijiang spruce, Norway spruce, and oriental spruce; Lijiang spruce, Norway spruce, and Schrenk's spruce.

Morinda spruce was characterized by the largest seeds (geometric mean diameter of $3.44 \mathrm{~mm}$, Table 2), whereas Sitka spruce and white spruce had the smallest seeds (geometric mean diameter of $1.68 \mathrm{~mm}$ ). Significant differences in geometric mean diameter were not observed in the following pairs of spruce species: Sitka spruce and white spruce, Jezo spruce and Meyer's spruce, Norway spruce and oriental spruce.

Table 2. Statistical distribution of the calculated indicators (mean value \pm standard deviation) of seeds in selected spruce species and significant differences between species.

\begin{tabular}{|c|c|c|c|c|c|c|}
\hline \multirow[b]{2}{*}{ Spruce Species } & \multicolumn{6}{|c|}{ Indicator } \\
\hline & $\begin{array}{c}\text { Geometric } \\
\text { Mean Diameter } \\
D(\mathrm{~mm})\end{array}$ & $\begin{array}{c}\text { Aspect Ratio } \\
\text { T/W (\%) }\end{array}$ & $\begin{array}{c}\text { Aspect Ratio } \\
T / L(\%)\end{array}$ & $\begin{array}{c}\text { Aspect Ratio } \\
W / L(\%)\end{array}$ & $\begin{array}{c}\text { Sphericity } \\
\text { Index } \Phi(\%)\end{array}$ & $\begin{array}{c}\text { Specific Mass } \\
m_{D}\left(\mathrm{~g} \mathrm{~m}^{-1}\right)\end{array}$ \\
\hline Blue spruce & $2.11 \pm 0.15^{c}$ & $81.81 \pm 8.50^{\mathrm{f}}$ & $39.17 \pm 3.93^{c}$ & $48.24 \pm 5.74^{\mathrm{a}, \mathrm{b}}$ & $57.27 \pm 3.71^{b, c}$ & $1.99 \pm 0.37^{c}$ \\
\hline Jezo spruce & $2.25 \pm 0.20^{\mathrm{d}}$ & $76.16 \pm 11.29^{c, d}$ & $38.19 \pm 4.60^{b, c}$ & $50.84 \pm 7.17^{c, d}$ & $57.72 \pm 3.92^{b, c, d}$ & $2.10 \pm 0.76^{c}$ \\
\hline Lijiang spruce & $2.48 \pm 0.23^{f}$ & $77.52 \pm 10.98^{\mathrm{d}, \mathrm{e}}$ & $36.72 \pm 4.71^{\mathrm{a}}$ & $47.79 \pm 5.63^{\mathrm{a}}$ & $55.83 \pm 3.76^{\mathrm{a}}$ & $2.77 \pm 0.62 \mathrm{~d}, \mathrm{e}$ \\
\hline Meyer's spruce & $2.28 \pm 0.21^{\mathrm{d}}$ & $77.40 \pm 10.59 \mathrm{~d}, \mathrm{e}$ & $39.27 \pm 4.34^{c}$ & $51.24 \pm 5.79^{\mathrm{c}, \mathrm{d}}$ & $58.46 \pm 3.41^{\mathrm{d}}$ & $2.64 \pm 0.53^{d}$ \\
\hline Morinda spruce & $3.44 \pm 0.21^{h}$ & $73.06 \pm 7.59^{a, b}$ & $42.08 \pm 3.53^{\mathrm{d}}$ & $57.98 \pm 5.65^{\mathrm{e}}$ & $62.39 \pm 3.14^{g}$ & $5.38 \pm 0.64^{\mathrm{f}}$ \\
\hline Norway spruce & $2.42 \pm 0.26^{\mathrm{e}}$ & $70.60 \pm 7.79^{\mathrm{a}}$ & $36.44 \pm 2.75^{\mathrm{a}}$ & $51.98 \pm 4.53^{\mathrm{d}}$ & $57.35 \pm 2.31^{b, c}$ & $2.79 \pm 0.63^{\mathrm{d}, \mathrm{e}}$ \\
\hline Oriental spruce & $2.38 \pm 0.21^{\mathrm{e}}$ & $79.07 \pm 9.64 \mathrm{e}^{\mathrm{e}}$ & $41.17 \pm 3.83^{\mathrm{d}}$ & $52.58 \pm 6.03^{d}$ & $59.92 \pm 3.40^{\mathrm{e}}$ & $2.70 \pm 0.56^{\mathrm{d}}$ \\
\hline Red spruce & $1.83 \pm 0.14^{b}$ & $75.75 \pm 9.22 b^{c, d}$ & $38.66 \pm 4.44^{c}$ & $51.63 \pm 7.56^{\mathrm{d}}$ & $58.29 \pm 4.53^{c, d}$ & $1.61 \pm 0.39^{b}$ \\
\hline Schrenk's spruce & $2.54 \pm 0.19 g$ & $73.49 \pm 10.74 \mathrm{~b}, \mathrm{c}$ & $35.99 \pm 3.89^{\mathrm{a}}$ & $49.63 \pm 6.43^{b, c}$ & $56.17 \pm 3.50^{\mathrm{a}}$ & $2.89 \pm 0.64^{\mathrm{e}}$ \\
\hline Sitka spruce & $1.68 \pm 0.12^{\mathrm{a}}$ & $76.12 \pm 11.20^{\mathrm{c}, \mathrm{d}}$ & $37.12 \pm 4.17^{\mathrm{a}, \mathrm{b}}$ & $49.62 \pm 8.11^{b, c}$ & $56.70 \pm 4.21^{\mathrm{a}, \mathrm{b}}$ & $1.36 \pm 0.25^{\mathrm{a}}$ \\
\hline White spruce & $1.68 \pm 0.14^{\mathrm{a}}$ & $85.29 \pm 9.21^{g}$ & $43.95 \pm 5.07^{\mathrm{e}}$ & $51.85 \pm 6.00^{\mathrm{d}}$ & $60.95 \pm 4.09^{\mathrm{f}}$ & $1.40 \pm 0.31^{\mathrm{a}}$ \\
\hline
\end{tabular}

$\mathrm{a}, \mathrm{b}, \mathrm{c}, \mathrm{d}, \mathrm{e}, \mathrm{f}, \mathrm{g}, \mathrm{h}$ — superscript letters denote significant differences between the corresponding properties.

The average values of the calculated aspect ratios were determined in the following range: $T / W$ ratio-from $70.60 \%$ (Norway spruce) to $85.29 \%$ (white spruce); $T / L$ ratio-from $35.99 \%$ (Schrenk's spruce) to $43.95 \%$ (white spruce); $W / L$ ratio-from $47.79 \%$ (Lijiang spruce) to $57.98 \%$ (Morinda spruce). The following spruce species differed considerably from the remaining species in terms of selected aspect ratios: blue spruce ( $T / W$ ratio), Morinda spruce $(W / L$ ratio), and white spruce $(T / W$ and $T / L$ ratios).

The sphericity index was highest in the seeds of Morinda spruce $(62.39 \%)$ and lowest in the seeds of Lijiang spruce (55.83\%). The analyzed seeds formed seven homogeneous groups in terms of the average values of the sphericity index. Morinda spruce, oriental spruce, and white spruce seeds formed separate groups.

The average specific mass of spruce seeds varied widely from $1.36 \mathrm{~g} \mathrm{~m}^{-1}$ (Sitka spruce) to $5.38 \mathrm{~g} \mathrm{~m}^{-1}$ (Morinda spruce). The above species produced the smallest and the largest seeds, respectively, containing the largest and the smallest number of empty spaces, respectively, in parenchymal tissue. The seeds of Morinda spruce and red spruce differed most significantly from the remaining species in this respect.

\subsection{Correlations between Seed Properties}

As previously mentioned, germination efficiency is significantly influenced by seed mass, a trait that cannot be reliably used to sort seeds into fractions. For this reason, the correlations between seed mass and the remaining physical properties were determined in this study. A linear correlation analysis of the above parameters (Table 3) revealed that seed mass was least influenced by the angle of external friction. Seed mass was most highly correlated with terminal velocity (six spruce species), seed length (Meyer's spruce, Morinda spruce, and Norway spruce), and seed thickness (Sitka's spruce and white spruce). A strong correlation was also noted between seed mass and seed thickness, and the values of the relevant correlation coefficients were always higher than the coefficients of correlation 
between seed mass and seed width. These results indicate that spruce seeds should be sorted with the use of mesh sieves with longitudinal rather than round openings.

Table 3. Coefficients of linear correlation between mass and the remaining physical properties of spruce seeds.

\begin{tabular}{cccccc}
\hline \multirow{2}{*}{ Spruce Species } & \multicolumn{4}{c}{ Coefficient of Correlation between Seed Mass $m$ and: } \\
\cline { 2 - 5 } & $\begin{array}{c}\text { Terminal } \\
\text { Velocity } v\end{array}$ & Thickness $T$ & Width $W$ & Length $L$ & $\begin{array}{c}\text { Angle of External } \\
\text { Friction } \alpha\end{array}$ \\
\hline Blue spruce & $0.610^{*}$ & $0.538^{*}$ & $0.459^{*}$ & $0.516^{*}$ & 0.101 \\
Jezo spruce & $0.866^{*}$ & $0.573^{*}$ & $0.264^{*}$ & $0.455^{*}$ & $-0.594^{*}$ \\
Lijiang spruce & $0.765^{*}$ & $0.658^{*}$ & $0.653^{*}$ & $0.597^{*}$ & $-0.320^{*}$ \\
Meyer's spruce & $0.617^{*}$ & $0.747^{*}$ & $0.575^{*}$ & $0.798^{*}$ & $-0.488^{*}$ \\
Morinda spruce & $0.418^{*}$ & $0.688^{*}$ & $0.529^{*}$ & $0.753^{*}$ & 0.045 \\
Norway spruce & $0.654^{*}$ & $0.881^{*}$ & $0.759^{*}$ & $0.920^{*}$ & $-0.190^{*}$ \\
Oriental spruce & $0.782^{*}$ & $0.748^{*}$ & $0.640^{*}$ & $0.778^{*}$ & $-0.302^{*}$ \\
Red spruce & $0.533^{*}$ & $0.479^{*}$ & $0.354^{*}$ & $0.453^{*}$ & -0.164 \\
Schrenk's spruce & $0.783^{*}$ & $0.503^{*}$ & $0.387^{*}$ & $0.434^{*}$ & -0.167 \\
Sitka spruce & $0.515^{*}$ & $0.592^{*}$ & $0.349^{*}$ & $0.476^{*}$ & -0.138 \\
White spruce & $0.374^{*}$ & $0.613^{*}$ & $0.443^{*}$ & $0.599^{*}$ & -0.149 \\
\hline
\end{tabular}

Significant correlations (0.05) were observed in 49 out of 55 comparisons (pairs). The correlation coefficient was practically significant (higher than 0.4 ) in 41 cases. The highest value of correlation coefficient (0.92) was noted between the mass and length of Norway spruce seeds.

In further analysis, the measured parameters of spruce seeds were pooled into a single experimental group. The correlations between the basic physical dimensions of seeds were determined by testing various regression functions (Figure $2 a-d$ ). Quadratic functions best fit empirical data (equations with the highest coefficient of determination). An equation with the highest percentage of explained variation (0.88) was obtained for the correlation between seed mass and seed thickness. An increase in seed thickness from around $0.9 \mathrm{~mm}$ to around $2.8 \mathrm{~mm}$ was accompanied by an estimated $1800 \%$ increase in seed mass (from $1.5 \mathrm{mg}$ to $28.3 \mathrm{mg}$ ). Seed mass significantly influences germination efficiency and germination rate; therefore, spruce seeds should be sorted into fractions based mainly on their thickness. The above approach is also dictated by the significant correlation between seed thickness and specific mass (coefficient of determination-0.82). Seed length, seed width, and terminal velocity could be used as secondary rather than primary distinguishing features in seed separation processes (the coefficient of determination for terminal velocity was determined at 0.70 ; the relevant equation is not presented in this paper). 


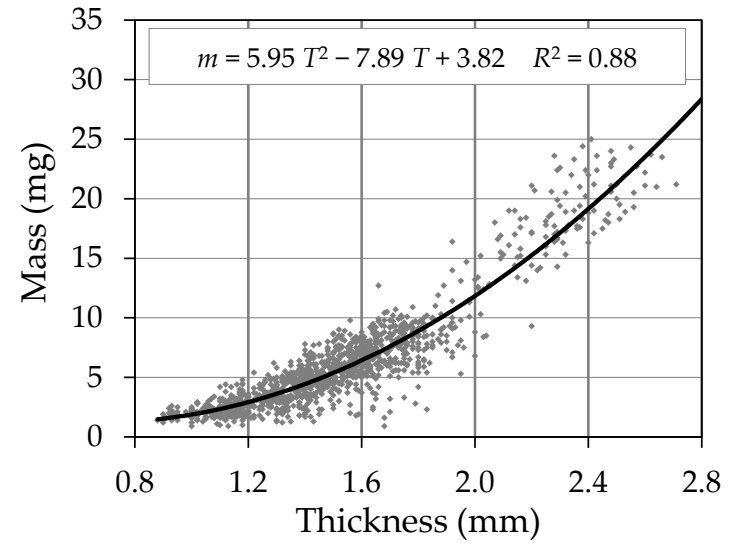

(a)

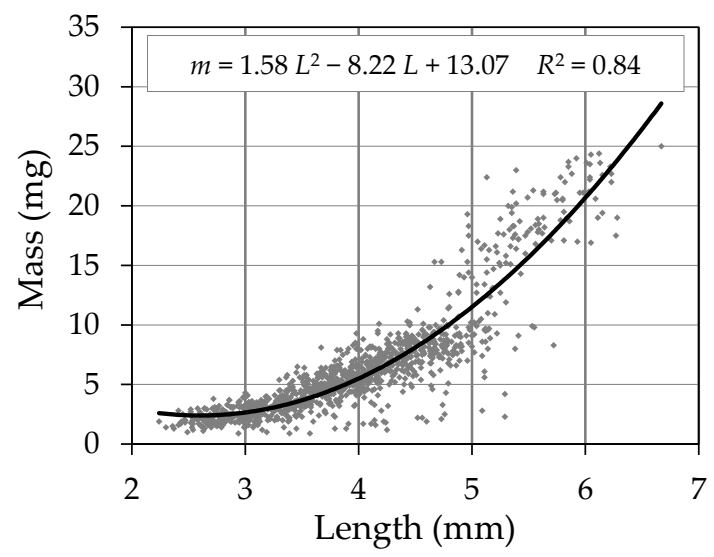

(c)

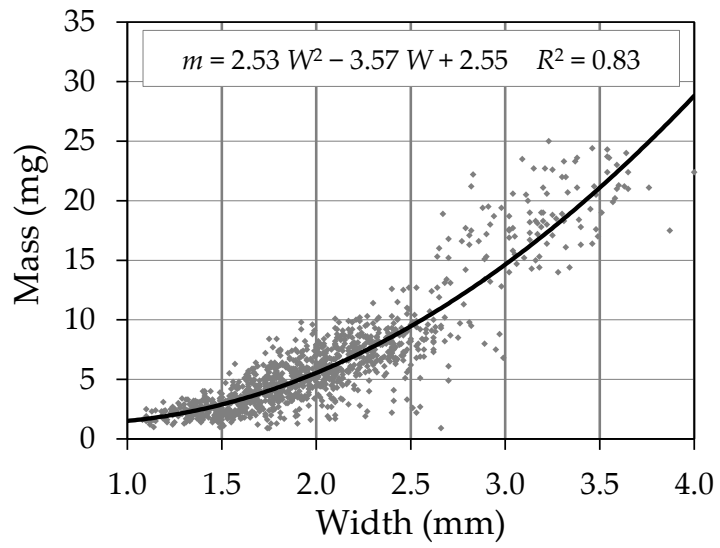

(b)

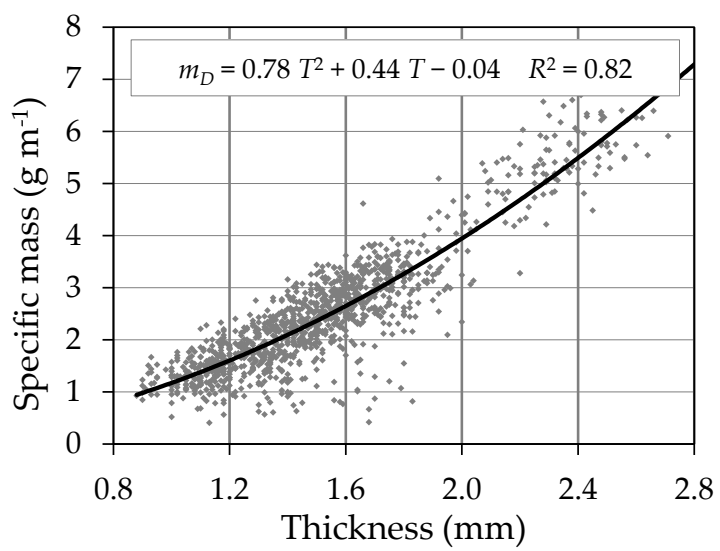

(d)

Figure 2. Relationships between the physical properties of spruce seeds: (a) thickness and mass; (b) width and mass; (c) length and mass; (d) thickness and specific mass.

The results of the analysis (Table 4) indicate that spruce seeds sorted based on seed thickness produce fractions with uniform seed mass. Before sorting, the coefficient of variation of seed mass ranged from around 17\% (Morinda spruce) to around 41\% (Jezo spruce), and it decreased in the sorted fractions. Medium-sized seeds (6 out of 11 cases) and large seeds (5 out of 11 cases) were least differentiated in terms of mass. In the analyzed seed groups, the coefficient of variation of seed mass differed across species and ranged from around 10\% (group III, Morinda spruce) to around 39\% (group I, Jezo spruce). After sorting, group II seeds of Norway spruce were most uniform in terms of seed mass (change of approx. 54.6\%), whereas group I seeds of blue spruce were least uniform in terms of seed mass (change of approx. 3.5\% relative to unsorted material). The following mesh sieves should be used to separate group I seeds of the analyzed spruce species: $\neq 1.05 \mathrm{~mm}$ (Sitka spruce), $\neq 1.15 \mathrm{~mm}$ (red and white spruce) $\neq 1.40 \mathrm{~mm}$ (blue spruce, Jezo spruce, Meyer's spruce), $\neq 1.45 \mathrm{~mm}$ (Norway spruce), $\neq 1.55 \mathrm{~mm}$ (Lijiang spruce, oriental spruce, Schrenk's spruce), and $\neq 2.25 \mathrm{~mm}$ (Morinda spruce). The following mesh sieves should be used to separate group III seeds: $\neq 1.15 \mathrm{~mm}$ (Sitka spruce),$\neq 1.25 \mathrm{~mm}$ (red and white spruce),$\neq 1.50 \mathrm{~mm}$ (blue spruce) $\neq 1.55 \mathrm{~mm}$ (Jezo spruce), $\neq 1.60 \mathrm{~mm}$ (Meyer's spruce and Norway spruce), $\neq 1.70 \mathrm{~mm}$ (oriental spruce and Schrenk's spruce), $\neq 1.75 \mathrm{~mm}$ (Lijiang spruce), and $\neq 2.40 \mathrm{~mm}$ (Morinda spruce). 
Table 4. Coefficient of variation of seed mass in three fractions of spruce seeds.

\begin{tabular}{|c|c|c|c|c|}
\hline \multirow{2}{*}{ Spruce Species } & \multirow{2}{*}{ Seed Fraction } & \multirow{2}{*}{ Percentage (\%) } & \multicolumn{2}{|c|}{ Coefficient of Variation (\%) of Seed Mass } \\
\hline & & & Fraction & Total \\
\hline \multirow{3}{*}{ Blue spruce } & $\mathrm{I}(T \leq 1.40 \mathrm{~mm})$ & 39.1 & 21.31 & \multirow{3}{*}{22.08} \\
\hline & II $(T=1.41 \div 1.50 \mathrm{~mm})$ & 33.9 & 14.43 & \\
\hline & III $(T>1.50 \mathrm{~mm})$ & 27.0 & 18.31 & \\
\hline \multirow{3}{*}{ Jezo spruce } & $\mathrm{I}(T \leq 1.40 \mathrm{~mm})$ & 30.1 & 38.80 & \multirow{3}{*}{41.15} \\
\hline & $\mathrm{II}(T=1.41 \div 1.55 \mathrm{~mm}$ & 34.4 & 30.93 & \\
\hline & III $(T>1.55 \mathrm{~mm})$ & 35.5 & 38.26 & \\
\hline \multirow{3}{*}{ Lijiang spruce } & $\mathrm{I}(T \leq 1.55 \mathrm{~mm})$ & 30.4 & 26.53 & \multirow{3}{*}{28.46} \\
\hline & II $(T=1.56 \div 1.75 \mathrm{~mm})$ & 41.9 & 23.76 & \\
\hline & III $(T>1.75 \mathrm{~mm})$ & 27.7 & 20.11 & \\
\hline \multirow{3}{*}{ Meyer's spruce } & $\mathrm{I}(T \leq 1.40 \mathrm{~mm})$ & 26.7 & 24.37 & \multirow{3}{*}{27.61} \\
\hline & II $(T=1.41 \div 1.60 \mathrm{~mm})$ & 40.6 & 18.61 & \\
\hline & III $(T>1.60 \mathrm{~mm})$ & 32.7 & 20.73 & \\
\hline \multirow{3}{*}{ Morinda spruce } & $\mathrm{I}(T \leq 2.25 \mathrm{~mm})$ & 35.5 & 14.34 & \multirow{3}{*}{16.73} \\
\hline & II $(T=2.26 \div 2.40 \mathrm{~mm})$ & 34.6 & 13.11 & \\
\hline & III $(T>2.40 \mathrm{~mm})$ & 29.9 & 10.32 & \\
\hline \multirow{3}{*}{ Norway spruce } & $\mathrm{I}(T \leq 1.45 \mathrm{~mm})$ & 34.5 & 19.73 & \multirow{3}{*}{33.61} \\
\hline & $\mathrm{II}(T=1.46 \div 1.60 \mathrm{~mm})$ & 35.3 & 15.26 & \\
\hline & III $(T>1.60 \mathrm{~mm})$ & 30.2 & 23.54 & \\
\hline \multirow{3}{*}{ Oriental spruce } & $\mathrm{I}(T \leq 1.55 \mathrm{~mm})$ & 26.6 & 26.01 & \multirow{3}{*}{27.55} \\
\hline & $\mathrm{II}(T=1.56 \div 1.70 \mathrm{~mm})$ & 40.7 & 20.41 & \\
\hline & III $(T>1.70 \mathrm{~mm})$ & 32.7 & 16.02 & \\
\hline \multirow{3}{*}{ Red spruce } & $\mathrm{I}(T \leq 1.15 \mathrm{~mm})$ & 33.6 & 26.13 & \multirow{3}{*}{28.00} \\
\hline & II $(T=1.16 \div 1.25 \mathrm{~mm})$ & 30.0 & 23.12 & \\
\hline & III $(T>1.25 \mathrm{~mm})$ & 36.4 & 23.37 & \\
\hline \multirow{3}{*}{$\begin{array}{l}\text { Schrenk's } \\
\text { spruce }\end{array}$} & $\mathrm{I}(T \leq 1.55 \mathrm{~mm})$ & 29.1 & 23.12 & \multirow{3}{*}{25.59} \\
\hline & $\mathrm{II}(T=1.55 \div 1.70 \mathrm{~mm})$ & 40.9 & 18.33 & \\
\hline & III $(T>1.70 \mathrm{~mm})$ & 30.0 & 23.39 & \\
\hline \multirow{3}{*}{ Sitka spruce } & $\mathrm{I}(T \leq 1.05 \mathrm{~mm})$ & 35.8 & 19.94 & \multirow{3}{*}{22.40} \\
\hline & $\mathrm{II}(T=1.06 \div 1.15 \mathrm{~mm})$ & 35.8 & 17.92 & \\
\hline & III $(T>1.15 \mathrm{~mm})$ & 28.4 & 16.63 & \\
\hline \multirow{3}{*}{ White spruce } & $\mathrm{I}(T \leq 1.15 \mathrm{~mm})$ & 32.7 & 25.12 & \multirow{3}{*}{26.68} \\
\hline & $\mathrm{II}(T=1.16 \div 1.25 \mathrm{~mm})$ & 32.7 & 22.08 & \\
\hline & III $(T>1.25 \mathrm{~mm})$ & 34.6 & 18.82 & \\
\hline
\end{tabular}

\section{Discussion}

According to the literature [21,27,42-45], seed plumpness (i.e., seed dimensions and seed mass) is largely influenced by genetic factors, the age of maternal trees, and environmental conditions, mostly geographic location, habitat, distribution of fruit and seeds in the tree crown (height from the ground and orientation relative to the cardinal directions), and weather. Without taking the above considerations into account, the analyzed Norway spruce seeds were somewhat less plump than those studied by Oleksyn et al. [21], Tylek [46], Załęski [47], and Yehnjong et al. [48]; they were similar to the seeds investigated by Kluczyński [42]; and they were somewhat plumper than the seeds analyzed by Kaliniewicz et al. [37,49]. The above suggests that Norway spruce seeds evaluated in this study were characterized by average plumpness, and seed dimensions and seed mass were within the reference range for the species $[21,27,50]$. The remaining seed parameters and indices were similar to those noted by Kaliniewicz et al. $[37,49,51]$. The mass of the analyzed spruce seeds was similar to that of red spruce seeds from Ontario [22], Schrenk's spruce seeds from Tianshan Mountains [24], white spruce seeds from the Great Lakes region [52], and Morinda spruce seeds from Garhwal Himalaya [26]. White spruce seeds were similar to black spruce seeds [53] in terms of length and width. The seeds analyzed in the present study were characterized by average plumpness and could be regarded as representative of the studied spruce species. The aspect ratios and the sphericity index of the evaluated seeds were similar to those of wheat grains [54-56]. 
Pairs of spruce species characterized by significant similarities in all seed parameters were not identified in this study. The greatest similarities were observed between the seeds of Lijiang spruce and Schrenk's spruce, which did not differ significantly in terminal velocity, thickness, length, the angle of external friction, mass, $T / L$ ratio, sphericity index, or specific mass. In general, oriental spruce seeds differed most considerably from the remaining spruce species, whereas the seeds of Jezo spruce and Meyer's spruce were most similar to the remaining species. Therefore, the seeds of Jezo spruce and Meyer's spruce can be regarded as representative of the pine family and used to differentiate between the seeds of different spruce species. Aspect ratios $T / L$ and $W / L$ (five homogeneous groups) were the least differentiating traits, whereas seed length, seed mass, and geometric mean diameter (eight homogeneous groups) were the most differentiating attributes in the analyzed spruce seeds.

The absolute value of the coefficient of correlation between the physical attributes of spruce seeds and seed mass ranged from 0.045 to 0.920 , where the angle of external friction was least correlated with the remaining attributes. Our findings, in addition to the results reported by Tylek [57] in a study of European beech (Fagus silvatica L.) seeds and by Kaliniewicz et al. [58] in a study of fir seeds, suggest that the frictional properties of the seeds of forest trees and shrubs can be used as secondary rather than primary distinguishing features in seed separation processes. Based on the calculated values of correlation coefficients, terminal velocity should be the main parameter for separating spruce seeds into fractions, in particular in Jezo spruce, Lijiang spruce, and Schrenk's spruce seeds. This is consistent with the general practice of sorting seeds of forest trees and shrubs, where pneumatic separators are often deployed [27]. According to the literature [27,37,49,59-61], pneumatic separators can be effectively used to sort the seeds of European beech (Fagus silvatica L.), European hornbeam (Carpinus betulus L.), small-leaved lime (Tilia cordata Mill.), black locust (Robinia pseudoacacia L.), rowan (Sorbus aucuparia L.), grey alder (Alnus incana (L.) Moench), European silver fir (Abies alba Mill.), Scots pine (Pinus sylvestris L.), Norway spruce (Picea abies (L.) H. Karst), and European larch (Larix decidua Mill.). However, a regression equation with the highest coefficient of determination (0.88) was obtained for the correlation between seed mass and seed thickness, which indicates that seed thickness (Figure 2) is the most reliable parameter for separating spruce seeds. The regression equation illustrating the correlation between seed thickness and specific mass (with a minimum coefficient of determination) also indicates that spruce seeds should be sorted with the use of mesh sieves with longitudinal openings. Separation processes that rely on seed thickness produce fractions that differ in the content of parenchymal tissue. Germination rates and germination efficiency can be improved when these seed fractions are sown separately. Seed thickness also proved to be a more reliable separation trait than terminal velocity in studies of European beech [61], Norway spruce [49], and European silver fir (Abies alba Mill.) [58].

If a mesh sieve with longitudinal openings is not available, spruce seeds can also be sorted with a grain grader. A grain grader is particularly effective in sorting Meyer's spruce, Morinda spruce, and Norway spruce seeds. According to Grochowicz [25], a grain grader has an indented cylinder for separating ellipsoidal seeds, such as the grain of the principal grain species. Grain graders are generally not used in tree nurseries, but they could be effective in sorting the seeds of the analyzed spruce species due to similarities in the aspect ratios of spruce seeds and wheat grain. The low popularity of grain graders in tree nurseries can be probably attributed to their low throughput as well as the fact that they separate seeds into only two fractions. A seed separator equipped with a grading deck with flat, differently sized and shaped mesh sieves offers a much quicker and more effective alternative. Mesh sieves with longitudinal (seeds sorted based on thickness) and round openings (seeds sorted based on width) can be used separately or together, but sieves with round openings should move in a vertical throwing motion for best results [25]. A pneumatic separator is generally less effective, but it is a useful device for sorting blue spruce, Jezo spruce, Lijiang spruce, oriental spruce, red spruce, and Schrenk's spruce seeds.

As mentioned before, germination efficiency is largely affected by seed mass [27-34]. Heavier seeds are more likely to germinate and produce seedlings because plump seeds are more abundant in 
storage compounds that are essential for germination. Sorting procedures based on seed plumpness improve the evenness of germination, which is particularly important in tree nurseries because it facilitates the planning of nursery treatments. Seed sorting based on seed plumpness also eliminates empty seeds, which substantially improves the quality of seeding material [46]. The results of this study indicate that mesh sieves with longitudinal openings are more effective in producing seed fractions with uniform mass. The variations in seed mass decrease in every sorted fraction, from around $12.5 \%$ in Jezo spruce to around $41.9 \%$ in Norway spruce on average. Fine seeds (with potentially lowest germination capacity) and medium-sized seeds can be sown in rows or broadcast in conventional nurseries (by choosing the most appropriate seeding rate), whereas the plumpest seeds can be sown individually in beds or containers. The described approach will deliver the following benefits:

- effective seedling production through the rational use of space allocated to different seeds, which is a very important consideration in container nurseries;

- rational use of seeding material with minimal loss of potentially germinable seeds;

- environmental benefits-the genetic potential of seeding material is not depleted (some trees produce seeds whose size differs from the reference range for the species).

\section{Conclusions}

Sitka spruce and white spruce produce the smallest seeds, and oriental spruce produces the largest seeds.

The seeds of Jezo spruce and Meyer's spruce were most similar to the remaining spruce species in terms of their physical parameters.

Spruce seeds should be sorted primarily with the use of mesh sieves with longitudinal openings whose size should be adapted to spruce species.

The seeds of blue, Jezo, Lijiang, oriental, red, and Schrenk's spruce can also be sorted with pneumatic separators.

Author Contributions: conceptualization: Z.K.; methodology: Z.K. and Z.Z.; formal analysis: Z.K. and E.K.; investigation: Z.K.; resources: Z.K.; data curation: Z.Z.; writing—original draft preparation: Z.K. and E.K.; writing-review and editing: Z.K.; visualization: Z.K.; supervision: Z.K.; project administration: Z.K.; funding acquisition: Z.K.

Funding: This research received no external funding.

Conflicts of Interest: The authors declare no conflict of interest.

\section{References}

1. Jonson, O.; More, D. Przewodnik Collinsa Drzewa (Collins Tree Guide); Multico Oficyna Wydawnicza: Warszawa, Poland, 2009; pp. 100-115. ISBN 9788370736439. (In Polish)

2. Houston Durrant, T.; Mauri, A.; de Rigo, D.; Caudullo, G. Picea sitchensis in Europe: Distribution, habitat, usage and threats. In European Atlas of Forest Tree Species; San-Miguel-Ayanz, J., de Rigo, D., Caudullo, G., Houston Durrant, T., Mauri, A., Eds.; Off. EU: Luxembourg, 2016.

3. Uniyal, S.K.; Uniyal, A. Climate change and large-scale degradation of spruce: common pattern across the globe. Clim. Res. 2009, 38, 261-263. [CrossRef]

4. Jia, Z.R.; Wang, J.H.; Zhang, S.G. Pollen morphology and its phylogenetic implications in the genus Picea. Plant Syst. Evol. 2014, 300, 461-473. [CrossRef]

5. Ghimire, B.; Lee, C.; Yang, J.; Heo, K. Comparative leaf anatomy of some species of Abies and Picea (Pinaceae). Acta Bot. Bras. 2015, 29, 346-353. [CrossRef]

6. Li, L.; Sun, Y.; Zou, J.; Yue, W.; Wang, X.; Liu, J. Origin and speciation of Picea schrenkiana and Picea smithiana in the Center Asian Highlands and Himalayas. Plant Mol. Biol. Rep. 2015, 33, 661-672. [CrossRef] [PubMed]

7. Savill, P.; Wilson, S.; Mason, B.; Jinks, R.; Stokes, V.; Christian, T. Alternative spruces to Sitka and Norway. Part 2-Oriental or Caucasian spruce (Picea orientalis), and the american and asian spruces. Q. J. For. 2017, $111,88-97$. 
8. Croser, C.; Renault, S.; Franklin, J.; Zwiazek, J. The effect of salinity on the emergence and seedling growth of Picea mariana, Picea glauca and Pinus banksiana. Environ. Pollut. 2001, 115, 9-16. [CrossRef]

9. Li, Y.; Stocks, M.; Hemmilä, S.; Källman, T.; Zhu, H.; Zhou, Y.; Chen, J.; Liu, J.; Lascoux, M. Demographic histories of four spruce (Picea) species of the Qinghai-Tibetan Plateau and neighboring areas inferred from multiple nuclear loci. Mol. Biol. Evol. 2010, 27, 1001-1014. [CrossRef] [PubMed]

10. Brus, D.J.; Hengeveld, G.M.; Walvoort, D.J.J.; Goedhart, P.W.; Heidema, A.H.; Nabuurs, G.J.; Gunia, K. Statistical mapping of tree species over Europe. Eur. J. For. Res. 2012, 131, 145-157. [CrossRef]

11. Caudullo, G.; Tinner, W.; de Rigo, D. Picea abies in Europe: distribution, habitat, usage and threats. In European Atlas of Forest Tree Species; San-Miguel-Ayanz, J., de Rigo, D., Caudullo, G., Houston Durrant, T., Mauri, A., Eds.; Off. EU: Luxembourg, 2016.

12. Drössler, L.; Fahlvik, N.; Wysocka, N.K.; Hjelm, K.; Kuehne, C. Natural regeneration in a multi-layered Pinus sylvestris-Picea abies forest after target diameter harvest and soil scarification. Forests 2017, 8, 35. [CrossRef]

13. Nieuwenhuis, M.A.; Wills, J.M. The effect of cultivation technique on root architecture of young Sitka spruce (Picea sitchensis (Bong.) Carr.) trees on surface water gleys. New For. 2002, 24, 195-213. [CrossRef]

14. Li, C.; Liu, S.; Berninger, F. Picea seedlings show apparent acclimation to drought with increasing altitude in the eastern Himalaya. Trees 2004, 18, 277-283. [CrossRef]

15. Dumais, D.; Prévost, M. Management for red spruce conservation in Québec: The importance of some physiological and ecological characteristics-A review. For. Chron. 2007, 83, 378-392. [CrossRef]

16. Lamontagne, J.M.; Boutin, S. Local-scale synchrony and variability in mast seed production patterns of Picea glauca. J. Ecol. 2007, 95, 991-1000. [CrossRef]

17. Shibata, E.; Saito, M.; Tanaka, M. Deer-proof fence prevents regeneration of Picea jezoensis var. hondoensis through seed predation by increased woodmouse populations. J. For. Res. 2008, 13, 89-95. [CrossRef]

18. Mckenzie, A.J.; Petty, S.J.; Toms, M.P.; Furness, R.W. Importance of Sitka spruce Picea sitchensis seed and garden bird-feeders for Siskins Carduelis spinus and Coal Tits Periparus ater. Bird Study 2010, 54, 236-247. [CrossRef]

19. Dumais, D.; Prévost, M. Germination and establishment of natural red spruce (Picea rubens) seedlings in silvicultural gaps of different sizes. For. Chron. 2016, 92, 90-100. [CrossRef]

20. Dylewski, L. Ecology and evolution of interaction between seed predators and conifers. Edukacja Ekologiczna 2016, 4, 3-8. (In Polish)

21. Oleksyn, J.; Modrzyński, J.; Tjoelker, M.G.; Żytkowiak, R.; Reich, P.B.; Karolewski, P. Growth and physiology of Picea abies populations from elevational transects: Common garden evidence for altitudinal ecotypes and cold adaptation. Funct. Ecol. 1998, 12, 573-590. [CrossRef]

22. Mosseler, A.; Major, J.E.; Simpson, J.D.; Daigle, B.; Lange, K.; Park, Y.-S.; Johnsen, K.H.; Rajora, O.P. Indicators of population viability in red spruce, Picea rubens. I. Reproductive traits and fecundity. Can. J. Bot. 2000, 78, 928-940. [CrossRef]

23. Luo, J.; Zhang, X.; Gu, W. Biogeographic differences in cone, needle and seed morphology among natural Picea asperata populations in Western China. For. Stud. China 2005, 7, 1-6. [CrossRef]

24. Liu, G.F.; Zang, R.G.; Liu, H.; Bai, Z.Q.; Guo, Z.J.; Ding, Y. Geographic variation of seed morphological traits of Picea schrenkiana var. tianschanica in Tianshan Mountains, Xinjiang of Northwest China. Chin. J. Appl. Ecol. 2012, 23, 1455-1461.

25. Grochowicz, J. Maszyny do Czyszczenia i Sortowania Nasion (Seed Cleaning and Sorting Machines); Akademia Rolnicza: Lublin, Poland, 1994; pp. 25-28. ISBN 839016129X. (In Polish)

26. Rawat, B.S.; Uniyal, A.K. Variability in cone and seed characteristics and seed testing in various provenances of Himalayan spruce (Picea smithiana). J. For. Res. 2011, 22, 603-610. [CrossRef]

27. Załęski, A. Nasiennictwo Leśnych Drzew I Krzewów Iglastych (Management of Coniferous Forest Trees and Shrubs for Seed Production); Oficyna Edytorska Wydawnictwo Świat: Warszawa, Poland, 1995; pp. 117-121. ISBN 8385597271. (In Polish)

28. Khan, M.L. Effects of seed mass on seedling success in Artocarpus heterophyllus L., a tropical tree species of north-east India. Acta Oecol. 2004, 25, 103-110. [CrossRef]

29. Parker, W.C.; Noland, T.L.; Morneault, A.E. The effects of seed mass on germination, seedling emergence, and early seedling growth of eastern white pine (Pinus strobus L.). New For. 2006, 32, 33-49. [CrossRef]

30. Jones, T.A.; Reekie, E.G. Effect of seed size on seedling growth response to elevated $\mathrm{CO}_{2}$ in Picea abies and Picea rubens. Plant Biol. 2007, 9, 766-775. [CrossRef] [PubMed] 
31. Upadhaya, K.; Pandey, H.N.; Law, P.S. The effect of seed mass on germination, seedling survival and growth in Prunus jenkinsii Hook.f. \& Thoms. Turk. J. Bot. 2007, 31, 31-36. [CrossRef]

32. Barbour, J.R.; Carvaiho, J.P.F. Response of Rocky Mountain juniper (Juniperus scopulorum) seeds to seed conditioning and germination treatments. Seed Technol. 2009, 31, 43-54.

33. Norden, N.; Daws, M.I.; Antoine, C.; Gonzalez, M.A.; Garwood, N.C.; Chave, J. The relationship between seed mass and mean time to germination for 1037 tree species across five tropical forests. Funct. Ecol. 2009, 23, 203-210. [CrossRef]

34. Mtambalika, K.; Munthali, C.; Gondwe, D.; Missanjo, E. Effect of seed size of Afzelia quanzensis on germination and seedling growth. Int. J. For. Res. 2014. [CrossRef]

35. Chaisurisri, K.; Edwards, D.G.W.; El-Kassaby, Y.A. Effects of seed size on seedling attributes in Sitka spruce. New For. 1994, 8, 81-87.

36. Kaliniewicz, Z.; Grabowski, A.; Liszewski, A.; Fura, S. Analysis of correlations between selected physical attributes of Scots pine seeds. Tech. Sci. 2011, 14, 13-22.

37. Kaliniewicz, Z.; Markowski, P.; Anders, A.; Jadwisieńczak, B.; Rawa, T.; Szczechowicz, D. Basic physical properties of Norway spruce (Picea abies (L.) Karst.) seeds. Tech. Sci. 2016, 19, 103-115.

38. Kaliniewicz, Z.; Poznański, A. Variability and correlation of selected physical attributes of small-leaved lime (Tilia cordata Mill.) seeds. Sylwan 2013, 157, 39-46. (In Polish)

39. Mohsenin, N.N. Physical Properties of Plant and Animal Materials; Gordon and Breach Science Public: New York, NY, USA, 1986; pp. 1-891. ISBN 9780677213705.

40. Kaliniewicz, Z. Analysis of frictional properties of cereal seed. Afr. J. Agric. Res. 2013, 8, 5611-5621. [CrossRef]

41. Rabiej, M. Statystyka z Programem Statistica (Statisctics in Statistica Software); Helion: Gliwice, Poland, 2012; pp. 1-344. ISBN 9788324641109. (In Polish)

42. Kluczyński, B. Yielding and quality of Norway spruce (Picea abies (L.) Karst) seeds in dependence on the part of crown and chosen biological and site-related characteristics of trees. Sylwan 1992, 5, 25-35. (In Polish)

43. Oleksyn, J.; Reich, P.B.; Tjoelker, M.G.; Chalupka, W. Biogeographic differences in shoot elongation pattern among European Scots pine populations. For. Ecol. Manag. 2001, 148, 207-220. [CrossRef]

44. Moles, A.T.; Westoby, M. Latitude, seed predation and seed mass. J. Biogeogr. 2003, 30, 105-128. [CrossRef]

45. Mezquida, E.T.; Benkman, C.W. The geographic selection mosaic for squirrels, crossbills and Aleppo pine. J. Evol. Biol. 2005, 18, 348-357. [CrossRef] [PubMed]

46. Tylek, P. Separation of fir, larch and spruce seeds based on seed mass. Prz. Tech. Rol. Leśn. 1999, 3, 17-19. (In Polish)

47. Załeski, A. The effect of different methods of Norway spruce seed extraction on their vitality and predisposition to long-term storage. For. Res. Pap. 2003, 1, 7-22. (In Polish)

48. Yehnjong, P.S.; Zavada, M.S.; Liu, C. Characterization and ecological significance of a seed bank from the Upper Pennsylvanian Wise Formation, southwest Virginia. Acta Palaeobot. 2017, 57, 165-175. [CrossRef]

49. Kaliniewicz, Z.; Markowski, P.; Anders, A.; Tylek, P.; Krzysiak, Z.; Fura, S. Influence of the age of parent stand on selected physical properties of Norway spruce seeds. Sylwan 2017, 161, 548-557. (In Polish)

50. Mikola, J. The effect of seed size and duration of growth on the height of Scots pine (Pinus sylvestris L.) and Norway spruce (Picea abies (L.) Karst.) provenances and progenies at the nursery stage. Silva Fenn. 1980, 14, 84-94. [CrossRef]

51. Kaliniewicz, Z.; Tylek, P.; Markowski, P.; Anders, A.; Rawa, T.; Zadrożny, M. Determination of shape factors and volume coefficients of seeds from selected coniferous trees. Tech. Sci. 2012, 15, 217-228.

52. Pike, C.C.; Warren, J.C.; Montgomery, R.A. Allometry of early growth in selected and wild sources of white spruce, Picea glauca (Moench) Voss. New For. 2016, 47, 131-141. [CrossRef]

53. Colas, F.; Lamhamedi, M.S. Production of a new generation of seeds through the use of somatic clones in controlled crosses of black spruce (Picea mariana). New For. 2014, 45, 1-20. [CrossRef]

54. Mabille, F.; Abecassis, J. Parametric modelling of wheat grain morphology: a new perspective. J. Cereal Sci. 2003, 37, 43-53. [CrossRef]

55. Markowski, M.; Żuk-Gołaszewska, K.; Kwiatkowski, D. Influence of variety on selected physical and mechanical properties of wheat. Ind. Crop. Prod. 2013, 47, 113-117. [CrossRef]

56. Kaliniewicz, Z.; Anders, A.; Markowski, P.; Jadwisieńczak, K.; Rawa, T. Influence of cereal seed orientation on external friction coefficients. Trans. ASABE 2016, 59, 1073-1081. [CrossRef] 
57. Tylek, P. Friction and elasticity as separation properties of beech nuts. Sylwan 2006, 5, 51-58.

58. Kaliniewicz, Z.; Mańkowski, S.; Tylek, P.; Krzysiak, Z.; Peda, W. Correlations between the physical properties of silver fir seeds. Acta Agroph. 2018, 25, 197-212. [CrossRef]

59. Tylek, P. Problems of pneumatic selection of forest tree seeds. Sylwan 1999, 12, 65-72. (In Polish)

60. Tylek, P. Analysis of aerodynamic properties of common fir and commmon beech. Inż. Rol. 2011, 6, $247-253$. (In Polish)

61. Kaliniewicz, Z.; Tylek, P.; Anders, A.; Markowski, P.; Rawa, T.; Ołdakowski, M.; Wasowski, L. An analysis of the physical properties of seeds of selected deciduous tree species. Balt. For. 2016, 22, 169-174. 